\title{
Review papers in Journal of Materials Science Volumes 30 and 31
}

\section{Volume 30 (1995)}

M. RAJA REDDY Effect of low earth orbit atomic oxygen on spacecraft materials, p. 281

S. PACKIRISAMY, D. SCHWAM and M.H. LITT Atomic oxygen resistant coatings for low earth orbit space structures, p. 308

D.E. LAWRYNOWICZ and E.J. LAVERNIA Sensors and techniques used to monitor processing parameters during spray atomization and deposition, p. 1125

C.C. WANG, S.A. AKBAR, W. CHEN and V.D. PATTON Electrical properties of high-temperature oxides, borides, carbides and nitrides, p. 1627

B.C. PAI, GEETHA RAMANI, R.M. PILLAI and K.G. SATYANARAYANA Roles of magnesium in cast aluminium alloy matrix composites, p. 1903

A.J. MARKWORTH, K.S. RAMESH and W.P. PARKS JR Modelling studies applied to functionally graded materials, p. 2183

B. HUYBRECHTS, K. ISHIZAKI and M. TAKATA The positive temperature coefficient of resistivity in barium titanate, p. 2463

YU.S. LIPATOV and L.V. KARABANOVA Gradient interpenetrating polymer networks, p. 2475

P. OSTOJIC Stress enhanced environmental corrosion and lifetime prediction modelling in silica optical fibres, p. 3011

Z. SUN and J.C. ION Laser welding of dissimilar metal combinations, p. 4205

M.A. MARTIN-LUENGO and M. YATES Zeolitic materials as catalysts for organic syntheses, p. 4483 J. JACOB, L.H.L. CHIA and F.Y.C. BOEY Thermal and non-thermal interaction of microwave radiation with materials, p. 5321

T.Z. TZVETKOFF, A. GIRGINOV and M. BOJINOV Corrosion of nickel, iron, cobalt and their alloys in molten salt electrolytes, p. 5561

\section{Volume 31 (1996)}

T.S.B. NARASARAJU and D.E. PHEBE Some physico-chemical aspects of hydroxyapatite, p. 1

K. KARASEK and M. SUMITA Characterization of dispersion state of filler and polymer-filler interactions in rubber-carbon black composites, p. 281

G.A. BIBO and P.J. HOGG The role of reinforcement architecture on impact damage mechanisms and post-impact compression behaviour, p. 1115

M.E. WESTWOOD, J.D. WEBSTER, R.J. DAY, F.H. HAYES and R. TAYLOR Oxidation protection for carbon fibre composites, p. 1389

C. DAYANAND, G. BHIKSHAMAIAH, V. JAYA TYAGARAJU, M. SALAGRAM and A.S.R. KRISHNA MURTHY Structural investigations of phosphate glasses: a detailed infrared study of the $x(\mathrm{PbO})-(1-x) \mathrm{P}_{2} \mathrm{O}_{5}$ vitreous system, p. 1945

W. J. PLUMBRIDGE Solders in electronics, p. 2501

M. KOTOUL Micromechanical and thermodynamical aspects of environmental crazing, p. 3333

M.C. ANDREWS, D.J. BANNISTER and R.J. YOUNG The interfacial properties of aramid/epoxy model composites, p. 3893 